\title{
Effects of dairy slurry on silage fermentation characteristics and nutritive value of alfalfa ${ }^{1}$
}

\author{
W. K. Coblentz, ${ }^{* 2}$ R. E. Muck, $†$ M. A. Borchardt, ${ }^{*}$ S. K. Spencer, ${ }^{*}$ W. E. Jokela, ${ }^{\star}$ M. G. Bertram, $\ddagger$ \\ and K. P. Coffey§ \\ *USDA-Agricultural Research Service, US Dairy Forage Research Center, Marshfield, WI 54449 \\ †USDA-Agricultural Research Service, US Dairy Forage Research Center, Madison, WI 53706 \\ fUniversity of Wisconsin Arlington Agricultural Research Station, Arlington 53911 \\ $\S$ Department of Animal Science, University of Arkansas, Fayetteville 72701
}

\section{ABSTRACT}

Dairy producers frequently ask questions about the risks associated with applying dairy slurry to growing alfalfa (Medicago sativa L.). Our objectives were to determine the effects of applying dairy slurry on the subsequent nutritive value and fermentation characteristics of alfalfa balage. Dairy slurry was applied to 0.17-ha plots of alfalfa; applications were made to the second (HARV1) and third (HARV2) cuttings during June and July of 2012, respectively, at mean rates of $42,400 \pm 5271$ and $41,700 \pm 2397 \mathrm{~L} / \mathrm{ha}$, respectively. Application strategies included (1) no slurry, (2) slurry applied directly to stubble immediately after the preceding harvest, (3) slurry applied after $1 \mathrm{wk}$ of post-ensiled regrowth, or (4) slurry applied after 2 wk of regrowth. All harvested forage was packaged in large, rectangular bales that were ensiled as wrapped balage. Yields of DM harvested from HARV1 (2,477 $\mathrm{kg} / \mathrm{ha})$ and HARV2 $(781 \mathrm{~kg} / \mathrm{ha})$ were not affected by slurry application treatment. By May 2013, all silages appeared to be well preserved, with no indication of undesirable odors characteristic of clostridial fermentations. Clostridium tyrobutyricum, which is known to negatively affect cheese production, was not detected in any forage on either a pre- or post-ensiled basis. On a pre-ensiled basis, counts for Clostridium cluster 1 were greater for slurry-applied plots than for those receiving no slurry, and this response was consistent for HARV1 (4.44 vs. $3.29 \log _{10}$ genomic copies/g) and HARV2 (4.99 vs. $3.88 \log _{10}$ genomic copies/g). Similar responses were observed on a post-ensiled basis; however, post-ensiled counts also were greater for HARV1 (5.51 vs. $5.17 \log _{10}$ genomic copies/g) and HARV2 (5.84

Received July 8, 2014.

Accepted August 14, 2014.

${ }^{1}$ Mention of trade names or commercial products in this article is solely for the purpose of providing specific information, and does not imply either recommendation or endorsement by the USDA.

${ }^{2}$ Corresponding author: wayne.coblentz@ars.usda.gov vs. $5.28 \log _{10}$ genomic copies/g) when slurry was applied to regrowth compared with stubble. For HARV2, counts also were greater following a 2-wk application delay compared with a 1 -wk delay (6.23 vs. $5.45 \log _{10}$ genomic copies/g). These results suggest that the risk of clostridial fermentations in alfalfa silages is greater following applications of slurry. Based on pre- and postensiled clostridial counts, applications of dairy slurry on stubble are preferred (and less risky) compared with delayed applications on growing alfalfa.

Key words: alfalfa, clostridia, dairy slurry, nutritive value, silage fermentation

\section{INTRODUCTION}

Dairy producers located in the north-central United States are increasingly seeking more land area on which to distribute dairy manure, largely in response to requirements for responsible management of nutrient loads. Currently, many states require nutrient management plans tailored for each specific dairy enterprise that establish thresholds for manure application rates that are based on $\mathrm{N}$ or $\mathrm{P}$ requirements for crop growth rather than the more practical, but sometimes urgent, need to empty manure-storage reservoirs. In addition, distribution of dairy manure has been increasingly associated with production of corn (Zea mays L.), especially corn silage, thereby limiting application windows to early spring or after fall harvest. This paradigm has been exacerbated in recent years because of greater dependence on corn silage to meet forage needs, increased size of dairy herds, and the poorer harvest efficiencies associated with multiple harvests of perennial forage crops. The close association of manure application with corn production can be problematic for several reasons, including increased risk of nutrient runoff because of poor residual ground cover and increased producer stress when spring or fall weather is especially wet, thereby prohibiting heavy equipment traffic across fields. The critical need for summer or 
other windows of opportunity for manure hauling has been identified previously (Rotz et al., 2005; Hedtcke et al., 2011). Although potential management strategies that open summer windows of opportunity for manure hauling have largely targeted perennial grasses, such as orchardgrass (Dactylis glomerata L.), as sites to receive manure (Hedtcke et al., 2011), producers also ask questions frequently about the advantages and disadvantages of applying manure to growing alfalfa. Extension materials have been developed to provide guidance for this management option (Lory et al., 2000; Ketterings et al., 2006; Rankin, 2006).

Within this context, one caution mentioned commonly is to avoid salt burn, which is caused by applications of dairy slurry to immature alfalfa regrowth that is particularly sensitive to ammonium and salts in the manure (Lory et al., 2000; Ketterings et al., 2006; Rankin, 2006). It has also been suggested that saltburned hay may be less acceptable to livestock than undamaged hay (Lory et al., 2000). For alfalfa, the extent of damage from salt burn or smothering varies with the application rate of solids and the timing of rain or irrigation after applications of manure (Lamb et al., 2005; Ketterings et al., 2007). Another potential problem with applying dairy slurry onto growing alfalfa is the potential inoculation of alfalfa silage with various microorganisms, such as enterobacteria and clostridia (Buxton and O'Kiely, 2003), both of which are known for their deleterious effects on silage fermentation and quality. Generally, enterobacteria can be controlled by good ensiling techniques, and reductions in their numbers reflects good ensiling conditions, adequate availability of nutrients and water, and efficient conversion of those nutrients to fermentation products yielding a low silage pH (Pahlow, et al., 2003). Because the magnitude of DM and energy losses associated with clostridial silage fermentations can be severe (McDonald et al., 1991), control of clostridial fermentations has been researched extensively, particularly in northern Europe, where wilting conditions are poor. Within this context, 3 general types of clostridia have been identified. Saccharolytic clostridia primarily ferment sugars and organic acids (including lactic acid), yielding butyric acid, carbon dioxide, and hydrogen, but exhibit little activity against proteins or AA (Muck, 1988; McDonald et al., 1991; Rooke and Hatfield, 2003). One specific example of saccharolytic clostridia is Clostridium tyrobutyricum, which can survive the ruminant digestive tract, compromise milk quality via fecal contamination of the udder, and is associated negatively with cheese production through the phenomenon known as late blowing (Pahlow et al., 2003). In contrast, proteolytic clostridia, such as Clostridium sporogenes, largely ferment AA, resulting in various undesirable end prod- ucts, particularly ammonia and amines (Muck, 1988; McDonald et al., 1991; Rooke and Hatfield, 2003). Some clostridia [Clostridium perfringens (welchii)] may exhibit both saccharolytic and proteolytic activities (McDonald et al., 1991). Generally, the end products of clostridial fermentations are not as acidic as lactic acid, thereby elevating silage $\mathrm{pH}$ and destabilizing the silage mass (Rooke and Hatfield, 2003). Perhaps more importantly, several reviews (Muck, 1988; Weiss et al., 2003) have concluded that the greater concentrations of amines, ammonia, and butyric acid within clostridial silages are likely to have a negative effect on voluntary intake by ruminant livestock. Furthermore, clostridia are spore formers, which enable them to resist desiccation, and survive while adhered to standing forage for long periods of time (Davies et al., 1996).

Although direct cause and effect relationships are difficult to establish independent of other management or environmental factors, several studies (Rammer et al., 1994, 1997; Davies et al., 1996; Rammer and Lingvall, 1997) have linked manure application to higher clostridial spore counts on a pre- or post-ensiled basis, or with greater concentrations of ammonia or butyric acid within mostly wet (often direct-cut) grass silages in northern Europe. Considerably less research is available evaluating the effects of dairy slurry applied to growing alfalfa or other legumes. Currently, a maximum moisture concentration of $70 \%$ is recommended when ensiling alfalfa (Muck et al., 2003), primarily to avoid clostridial fermentations; alfalfa is especially susceptible to these problematic fermentations because it has relatively low concentrations of water-soluble carbohydrates (WSC) and a greater buffering capacity (BC) than cool-season grasses (Albrecht and Beauchemin, 2003). In addition, dairy slurry may not only affect clostridial counts associated with alfalfa at ensiling, but summaries of studies with cool-season grasses also suggest that application of slurry may negatively affect the sugar concentrations and reduce the buffering capacity of the pre-ensiled crop (Buxton and O'Kiely, 2003). Our objectives for the current study were to assess the effects of dairy slurry application on silage fermentation, clostridial counts, and the forage nutritive value of alfalfa silages conserved as balage.

\section{MATERIALS AND METHODS}

\section{Field Procedures}

Description of Field Site and Experimental Layout. A 2.7-ha site on the University of Wisconsin Marshfield Agricultural Research Station, located near Stratford, Wisconsin $\left(44^{\circ} 7^{\prime} \mathrm{N}, 90^{\circ} 1^{\prime} \mathrm{W}\right)$, was selected for the experiment. The soil type at that location was 
Table 1. Application rates and composition (\% of DM unless otherwise noted) of dairy slurry applied to growing alfalfa during 2012 at Marshfield, Wisconsin ${ }^{1}$

\begin{tabular}{|c|c|c|c|c|c|c|c|c|c|c|c|}
\hline Item & $\begin{array}{l}\text { Density } \\
(\mathrm{kg} / \mathrm{L})\end{array}$ & $\begin{array}{l}\text { Application } \\
\text { rate }(\mathrm{L} / \mathrm{ha})\end{array}$ & $\begin{array}{l}\mathrm{DM} \\
(\%)\end{array}$ & $\mathrm{N}$ & $\mathrm{NH}_{4}-\mathrm{N}$ & $\mathrm{P}$ & K & S & Ash & $\begin{array}{l}\mathrm{C}: \mathrm{N} \\
\text { ratio }\end{array}$ & $\begin{array}{c}\text { Clostridial } \\
\text { cluster } 1 \\
\left(\log _{10} \text { genomic }\right. \\
\text { copies } / \mathrm{g})\end{array}$ \\
\hline Mean & 1.08 & 42,400 & 6.4 & 3.8 & 1.8 & 0.75 & 3.7 & 0.29 & 41.9 & 9.0 & 6.97 \\
\hline $\mathrm{SD}$ & 0.062 & 5,271 & 2.21 & 0.63 & 0.39 & 0.132 & 0.88 & 0.023 & 5.20 & 0.82 & 0.179 \\
\hline \multicolumn{12}{|c|}{ Harvest 2} \\
\hline \multicolumn{12}{|c|}{ Both harvests } \\
\hline Mean & 1.07 & 42,100 & 5.7 & 3.9 & 1.7 & 0.77 & 4.1 & 0.30 & 36.1 & 9.7 & 6.89 \\
\hline $\mathrm{SD}$ & 0.063 & 4,110 & 1.84 & 0.52 & 0.32 & 0.105 & 0.92 & 0.026 & 6.56 & 1.02 & 0.181 \\
\hline
\end{tabular}

${ }^{1}$ Clostridium tyrobutyricum was not detected within dairy slurry applied for either harvest.

a Loyal silt loam (fine-loamy, mixed Oxyaquic Glossoboralfs). The site was subdivided, primarily on the basis of topography (slope), into 4 experimental blocks of equal size (0.68 ha). Within each field block, 4 adjacent $14-\times 122-\mathrm{m}(0.17-\mathrm{ha})$ rectangular plots were positioned with a north-to-south orientation; therefore, a total of 16 field plots (experimental units) were used within the study.

Application of Dairy Slurry. Each dairy slurry application treatment was assigned to 1 plot within each block. Treatments included (1) no slurry (control); (2) slurry applied to alfalfa stubble immediately following harvest; (3) slurry applied to alfalfa after 1 wk of regrowth; or (4) slurry applied to alfalfa after 2 wk of regrowth. On June 1, 2012, the first cutting of Pioneer 55V48 alfalfa from the experimental field area was removed as haylage; dairy slurry was then applied to plots assigned to the stubble application treatment on June 4. Similarly, slurry was distributed on plots assigned to delayed application treatments (after 1 or 2 wk of alfalfa regrowth) on June 11 and 18. Dairy slurry was broadcast-applied on these June application dates with a Calumet Model 5000 Spreader (CalumetImperial Industries, Wausau, WI) at a mean rate of $42,400 \pm 5,271 \mathrm{~L} /$ ha. Application rates were calculated as the weight of slurry dispensed for each field plot $(\mathrm{kg})$ divided by the density of the slurry $(\mathrm{kg} / \mathrm{L})$; liters of dairy slurry applied per plot were then extrapolated mathematically to a liter per hectare basis. Weights of slurry applied to each plot were determined by driving the manure tanker across truck scales that weighed to the nearest $\pm 2.3 \mathrm{~kg}$. A 3.5-L sample of dairy slurry was taken from each spreader load after thorough agitation and analyzed for total $\mathrm{N}, \mathrm{NH}_{4}-\mathrm{N}, \mathrm{P}, \mathrm{K}, \mathrm{S}$, ash, and C:N ratio by the University of Wisconsin Soil and Forage Laboratory (Marshfield, WI). These compositional data, as well as application rate, slurry density, and enumeration of C. tyrobutyricum and Clostridium cluster 1 within the dairy slurry are summarized in Table 1.
Harvest 1. At $1300 \mathrm{~h}$ on July 10, the alfalfa from each of the 16 field plots (HARV1) was mowed and roll-conditioned in wide swaths with a self-propelled mower/conditioner (Case-International Harvester Model WD1903; CNH America LLC, Racine, WI). At $1015 \mathrm{~h}$ on July 11, alfalfa forage was merged, and then packaged in $0.9-\times 0.9-\times 1.8-\mathrm{m}(\sim 350 \mathrm{~kg}$, wet basis $)$ large, rectangular bales with a Case-International Harvester Model LB333 baler. For HARV1, a total of 33 bales were produced, which included bales produced at ideal moisture (Shinners, 2003) for wrapped silage bales (referred to as ideal bales; overall mean $=46.2 \%$ ), and bales produced approximately $3 \mathrm{~h}$ later $(1315 \mathrm{~h})$ at a relatively low moisture concentration for wrapped balage (referred to as dry bales; overall mean $=34.5 \%$ ). One plot produced sufficient forage to make 2 dry bales, but all others produced only 1 ideal and 1 dry bale. All bales produced during HARV1 were tagged, measured, and weighed; all forage from each plot was removed within these bales, and bale weights were used subsequently to determine yields of DM from each plot. Before bales were sealed in plastic wrap, six 0.61-mdeep core samples $(0.025-\mathrm{m}$ diameter) were obtained from one end of each bale using a Uni-Forage Sampler (Star Quality Samplers, Edmonton, AB, Canada). Air was displaced from the sample holes with spray-foam insulation; however, special attention ensured that the wet foam insulation did not directly contact the plastic when bales were wrapped shortly thereafter. All core samples were composited by bale, sealed in 3.8-L plastic freezer bags, placed on ice in insulated coolers, and then taken to the research laboratory for processing. Beginning at $1500 \mathrm{~h}$, each bale was wrapped with 0.75$m$ wide (unstretched) Flavor Seal (BENCO Poly Films, LLC; Leola, PA) white poly-stretch film (thickness = $25.4 \mu \mathrm{m}$ ) using an individual (single-bale) wrapper (Model 995 TSR; McHale Engineering Limited; Ballinrobe, Co. Mayo, Ireland) programed to apply 7 plastic layers (28 table revolutions) to each bale. After wrap- 
ping, bales were stored on a concrete pad until a final post-ensiled sampling date on May 29, 2013.

Harvest 2. For harvest 2 (HARV2), the assignment of dairy slurry application treatments to plots was not altered from assignments made for HARV1. Slurry was applied to alfalfa stubble or alfalfa regrowth of 1 or 2 wk at an overall mean rate of 41,700 $\pm 2,397$ L/ha on July 12, 20, and 26. Alfalfa forage was mowed and conditioned at approximately one-third bloom at $0930 \mathrm{~h}$ on August 10 as described previously, raked at $1530 \mathrm{~h}$ the same day, and then baled at $1045 \mathrm{~h}$ on August 11. Weather conditions during late July were particularly droughty during 2012, and sufficient DM was produced from HARV2 to make only 1 bale per field replication (ideal; overall mean initial moisture $=$ 49.1\%). All bales produced from HARV2 were tagged, measured, sampled, and wrapped as described previously, except that a shorter, 0.46-m-long sampling probe was used. This change was made because many of the bales were short (overall mean length $=0.89 \mathrm{~m}$ ), thereby reflecting the droughty growing conditions and limited forage produced, and it was our desire to limit the depth of sampling holes to approximately half the length of the bale. All wrapped bales from HARV2 were stored on a concrete pad until a final sampling date on May 31, 2013.

Post-Ensiled Sampling Procedures. After a storage period of 322 (HARV1) or 293 d (HARV2), each bale was rigorously sampled ( 8 to 9 cores per bale) with a $0.61-\mathrm{m}$ probe. All samples were collected on ice and then transported to the laboratory within insulated coolers for processing and subsequent laboratory analysis.

\section{Laboratory Procedures}

Silage. On a pre-ensiled basis, three 25 -g subsamples were removed from each sealed freezer bag after thorough mixing. One subsample was dried overnight in a convection oven at $105^{\circ} \mathrm{C}$ to determine the initial concentration of DM within each bale. A second 25-g subsample was used to assess the initial $\mathrm{pH}$ of each bale by adding $100 \mathrm{~mL}$ of deionized water and macerating for $30 \mathrm{~s}$ in a kitchen blender; the macerated contents were then filtered through 2 layers of cheesecloth, and evaluated for initial bale $\mathrm{pH}$ with a bench-top $\mathrm{pH}$ meter (Orion3Star; Thermo Fisher Scientific Inc., Waltham, MA). A third 25-g subsample was isolated within a separate freezer bag for subsequent enumeration of clostridia; this subsample was stored in an ultralow freezer at $-80^{\circ} \mathrm{C}$ until microbiological counts were completed. The remaining portion of the composite sample from each bale ( 200 to $300 \mathrm{~g})$ was placed in an ultralow freezer overnight to quickly suspend respi- ration and then transferred to a standard commercial freezer $\left(-20^{\circ} \mathrm{C}\right)$ the next day pending lyophilization and subsequent analysis of nutritive value, BC, WSC, and starch. Lyophilized samples were ground through a Thomas Model 4 Wiley Mill (Thomas Scientific, Swedesboro, NJ) fitted with a 1-mm screen. Buffering capacity was reported as milliequivalents of $\mathrm{HCl}$ per kilogram of forage DM needed to reduce $\mathrm{pH}$ from 6.0 to 4.0, determined as described by Muck and Walgenbach (1985) and further modified by Coblentz and Muck (2012). Water-soluble carbohydrates were extracted from a 0.25 -g sample of dried, ground forage in $150 \mathrm{~mL}$ of deionized water for $2 \mathrm{~h}$, followed by gravity filtering through Whatman \#1 filter paper (GE Healthcare UK Limited, Little Chalfont, UK). The phenol-sulfuric acid reaction was used to quantify WSC within aliquots of the extract, with final concentrations of WSC determined colorimetrically (Dubois et al., 1956). Concentrations of starch were determined (YSI, 2000) by enzymatic hydrolysis of starch molecules with amyloglucosidase; the resultant D-glucose monomers and $\mathrm{O}_{2}$ were converted by glucose oxidase to D-glucono- $\delta$-lactone and $\mathrm{H}_{2} \mathrm{O}_{2}$. The resultant $\mathrm{H}_{2} \mathrm{O}_{2}$ was oxidized electrochemically to yield a signal current (Model 2700D Bioanalyzer; Yellow Springs Instrument Co., Yellow Springs, OH), which was calibrated to liberated peroxide from known standards.

For post-ensiled samples, sample processing and analysis procedures were similar, except that determination of $\mathrm{BC}$ was omitted, and an additional 25-g subsample from each bale was sealed in a separate freezer bag, placed in an ultralow freezer overnight to quickly suspend respiration, and then transferred to a standard commercial freezer $\left(-20^{\circ} \mathrm{C}\right)$ pending analysis of fermentation acids and $\mathrm{NH}_{3}-\mathrm{N}$. Silage extracts were prepared in distilled water, followed by deproteinization with trichloroacetic acid as described by Muck (1987). Concentrations of $\mathrm{NH}_{3}-\mathrm{N}$ were determined as described by Broderick et al. (2004), whereas other relevant products of fermentation were quantified by HPLC techniques (Muck and Dickerson, 1988).

Nutritive Value. The fiber composition of dried, ground forage samples was analyzed sequentially for NDF, ADF, hemicellulose, cellulose, and ADL using batch procedures outlined by Ankom Technology Corp. (Macedon, NY) for an Ankom ${ }^{200}$ Fiber Analyzer. The NDF solution did not contain sodium sulfite or heatstable $\alpha$-amylase. Whole-plant ash was determined on 1.0-g samples of lyophilized forage following combustion in a muffle furnace at $500^{\circ} \mathrm{C}$ for $6 \mathrm{~h}$. Concentrations of total $\mathrm{N}$ within each sample were determined with a rapid combustion procedure (AOAC International, 1998, method 990.03; Elementar Americas Inc., Mt. Laurel, NJ), followed by conversion to $\mathrm{CP}$ using a fac- 
tor of 6.25. Forage CP also was partitioned into pools of neutral and acid detergent-insoluble CP (NDICP and ADICP, respectively) following nonsequential digestion in each respective solution. The NDF solution contained no heat-stable $\alpha$-amylase or sodium sulfite; the latter was omitted because it is known to cleave disulfide bonds and dissolve cross-linked proteins, which reduces protein recovery from NDF residues (Van Soest et al., 1991). Residual CP following these extractions was determined by the combustion procedure described previously (AOAC International, 1998). Estimates of energy density (TDN) were calculated for all forages from the summative equation (Weiss et al., 1992; NRC, 2001) using the ADL option for estimating truly digestible fiber.

Enumeration of Clostridia. Clostridia were eluted from forage samples by adding $18 \mathrm{~mL}$ of TrisEDTA buffer to $2 \mathrm{~g}$ of forage in a $50-\mathrm{mL}$ polypropylene test tube and shaking the mixture vigorously for $1 \mathrm{~min}$. Eluate was transferred to a clean test tube by serological pipet, using the pipet tip to squeeze and express liquid from the forage. The eluate was centrifuged at $4,500 \times g$ for 10 min at $4^{\circ} \mathrm{C}$ and the supernatant carefully discarded by pipetting, retaining the pellet and approximately $0.5 \mathrm{~mL}$ of liquid. Aseptic technique was applied throughout the elution procedure.

For DNA extraction, the pellet was resuspended, and then $0.6 \mathrm{~mL}$ of the suspension was transferred to a QIAshredder (Qiagen, Germantown, MD), followed by centrifugation at $6,000 \times g$ for $1 \mathrm{~min}$ at $4^{\circ} \mathrm{C}$. When necessary, the $1,000-\mu \mathrm{L}$ pipet tip was cut off to avoid blockage by forage debris. Pellet remaining in the sample tube was rinsed with $0.5 \mathrm{~mL}$ of Tris-EDTA buffer, loaded into the QIAshredder that had been transferred to a new filtrate collection tube, and centrifuged again. These steps were repeated until the entire pellet was shredded; all filtrates were combined and centrifuged at $20,000 \times g$ for $2 \mathrm{~min}$ at $4^{\circ} \mathrm{C}$. The supernatant was discarded, and $400 \mu \mathrm{L}$ of Tris-EDTA buffer, $40 \mu \mathrm{L}$ of proteinase K (Qiagen), and $400 \mu \mathrm{L}$ of AL buffer (Qiagen) were added to the pellet, followed by incubation at $56^{\circ} \mathrm{C}$ for $10 \mathrm{~min}$. Four-hundred microliters of absolute ethanol were added to each sample, and the DNA was purified by successive loading of 2 equal portions of the lysate onto a QIAamp DNA mini column (Qiagen) following the manufacturer's directions. Concentrations of DNA in extracted eluates $(50 \mu \mathrm{L})$ were measured using Quant-IT PicoGreen (Life Technologies, Grand Island, NY) with a GloMax-Multi Junior Fluorimeter (ProMega, Madison, WI). Among all forage samples $(\mathrm{n}=99)$, concentrations of DNA ranged from 1.24 to $3.88 \mathrm{ng} / \mu \mathrm{L}$. Manure samples were diluted 1:10 with sterile PBS, and then DNA was extracted from a 140- $\mu \mathrm{L}$ aliquot using the QIAamp DNA Mini kit. All DNA concentrates were stored at $-80^{\circ} \mathrm{C}$.

Quantitative PCR assays were conducted for 2 targets-C. tyrobutyricum flagellin gene and Clostridium cluster I 16S rRNA gene - using a LightCycler 480 realtime PCR system (Roche Diagnostics, Mannheim, Germany). In simple terms, Clostridium cluster I represents a group of genetically similar clostridia, grouped largely for describing the taxonomic arrangement of the genus (Collins et al., 1994). Cluster 1 includes C. tyrobutyricum, as well as several other clostridial strains (Clostridium tetani, Clostridium botulinum, and C. perfringens) that are widely known for their serious effects on human or animal health; within cluster 1 , both saccharolytic and proteolytic species exist (Collins et al., 1994). Reactions consisted of $6 \mu \mathrm{L}$ of extracted DNA and $14 \mu \mathrm{L}$ of master mix [LightCycler 480 Probes Master Kit (Roche Diagnostics)] for a total volume of $20 \mu \mathrm{L}$. Sequences of the primers and fluorescence-labeled hydrolysis probes and their reaction final concentrations were identical to those reported for C. tyrobutyricum (López-Enríquez et al., 2007) and for Clostridium cluster I (Song et al., 2004). However, our thermal cycling parameters differed; both targets were amplified by 1 cycle at $95^{\circ} \mathrm{C}$ for $10 \mathrm{~min}$ followed by 45 cycles of $15 \mathrm{~s}$ at $95^{\circ} \mathrm{C}$ and 1 min at $60^{\circ} \mathrm{C}$. Master mix and extraction no-template negative controls for both targets were conducted with every batch of reactions; all were negative (i.e., no fluorescence) throughout the study. Positive controls were gBlocks double-stranded gene fragments (Integrated DNA Technologies, Coralville, IA) custom-made to match primer and probe sequences, but with the remaining portion of the sequence randomly scrambled so positive control amplicons could be distinguished from the wild-type DNA targets. Lengths of gBlocks for $C$. tyrobutyricum and Clostridium cluster 1 targets were 133 and $250 \mathrm{bp}$, respectively. The gBlocks were diluted in Tris-EDTA buffer to create positive controls with cycle quantification $\left(\mathbf{C}_{\mathbf{q}}\right)$ values of approximately 32.0.

Standard curves were prepared from gBlocks stock (200 ng of lyophilized gBlocks in $100 \mu \mathrm{L}$ of Tris-EDTA buffer) serially diluted 10-fold in Tris-EDTA buffer, where the first standard was a 1:1,000 dilution. Standards ranged over 7 factors of 10 from $\mathrm{C}_{\mathrm{q}}$ values of approximately 17 to 38 . Number of genomic copies was calculated as (gBlocks mass $\times$ Avogadro constant)/ (gBlocks length $\times 650$ ), where the average DNA basepair is 650 Da. The LightCycler software calculated $\mathrm{C}_{\mathrm{q}}$ values using the second derivative maximum method and regressed these values against the $\log _{10}$ number of genomic copies. Standard curve efficiency and $\mathrm{r}^{2}$ values, respectively, were 2.056 and 0.9961 for C. tyrobutyricum, and 2.027 and 0.9982 for Clostridium cluster 1. 
Inhibition of PCR was measured for every sample following the approaches described by Borchardt et al. (2012) and Gibson et al. (2012). After DNA extraction, the sample was spiked with Lambda-phage genomic DNA (New England BioLabs Inc., Ipswich, MA) such that when PCR inhibition was absent in inhibition controls containing only PCR reagent-grade water and no sample, amplification of the Lambda DNA yielded a $\mathrm{C}_{\mathrm{q}}$ value of 30 . Amplification was conducted with the same thermal cycling conditions and master mix as described for the clostridial targets. Primers (final concentrations $500 \mathrm{n} M$ ) have been reported by Rutledge and Stewart (2010). The hydrolysis probe was designed in our laboratory, where the $5^{\prime} \rightarrow 3^{\prime}$ sequence was FAMCGTCAACGGCATCCACGAAGGCGACAGA-BBQ. Amplicon length was $151 \mathrm{bp}$, and Lambda-DNA amplification in extractions from all forage and manure samples yielded $\mathrm{C}_{\mathrm{q}}$ values within \pm 1 cycle of 30 , thereby suggesting none of the samples were PCR inhibited.

The effectiveness of our elution and extraction procedures for recovering clostridia from forage also was evaluated. Forage from dry bales obtained from HARV1 that had no dairy slurry applied was selected for these recovery experiments because it was likely that background clostridial counts (before spiking) would be low. A culture of $C$. perfringens in chopped meat broth incubated at $35^{\circ} \mathrm{C}$ was kindly provided to us by Marshfield Laboratories (Marshfield, WI). The culture was quantified with the Clostridium cluster I primer and probe set and diluted to a working stock of $7.6 \times 10^{7} / \mathrm{mL}$. Forage samples $(2 \mathrm{~g})$ were spiked with $100 \mu \mathrm{L}$ of $C$. perfringens working stock, and allowed to dry at room temperature for $10 \mathrm{~min}$ before conducting elution and extraction procedures. The Clostridium cluster I background concentration in the forage was $1.4 \times 10^{4}$ genomic copies/g. Five recovery experiments were performed; correcting for background, mean percent recovery was $40 \pm 15 \%( \pm 1 \mathrm{SD})$.

\section{Statistics}

All statistical analyses were conducted using PROC GLM of SAS Institute (2002). Data for HARV1 were analyzed as a split-plot design with 4 slurry application strategies designated as wholeplots, and initial bale moisture (ideal or dry) as subplots. Orthogonal contrasts were used to evaluate differences between slurry application strategies on a pre- and post-ensiled basis: (1) no slurry versus slurry; (2) immediate application to stubble versus delayed application; and (3) application delayed by 1 versus 2 wk. Individual contrasts were tested for significance using the slurry application treatment $\times$ block mean square as the error term. The subplot effect of moisture concentration (ideal vs. dry) was tested for significance with the residual error mean square. One original goal within the current project was to assess cumulative effects of repeated applications of dairy slurry across multiple harvests; however, the effects of drought conditions during 2012, especially during late summer, limited forage growth for HARV2 to one less-than-full-size bale per field replication that was packaged at ideal bale moisture. Therefore, HARV2 had to be condensed to a randomized complete block design with dairy slurry application strategies as treatments, thereby requiring HARV1 and HARV2 to be analyzed as separate experiments. For HARV2, the effects of application strategies were tested as described previously for HARV1, except that the residual error mean square was used as the error term to test for significance. Data enumerating clostridia were transformed as $\log _{10}$ (genomic copies/g) before conducting statistical analyses. Statistical significance was declared at the $P=0.05$ level of confidence.

\section{RESULTS AND DISCUSSION}

\section{Weather Data}

Total precipitation at the Marshfield Agricultural Research Station during 2012 was $740 \mathrm{~mm}$, which was well below the 30-yr norm ( $840 \mathrm{~mm}$; NOAA, 2002). More importantly, only $34 \mathrm{~mm}$ of precipitation occurred during July. Although precipitation during August 2012 (104 mm) was similar to the expected 30-yr norm, it was very poorly distributed, with $82 \%$ of the total associated with 3 rainfall events that occurred between August 2 and 9.

\section{Dairy Slurry Analysis}

The overall slurry application rate $(42,100 \pm 4,110 \mathrm{~L} /$ ha; Table 1) was within recent Wisconsin recommendations for applications onto established alfalfa $(28,000$ to $46,750 \mathrm{~L} / \mathrm{ha}$ ), which is typically reduced relative to recommended preplant application rates, in part to avoid burning of regrowth by salt and ammonium within the slurry (Rankin, 2006). Overall concentrations of DM $(5.7 \pm 1.84 \%)$ and $\mathrm{P}(0.77 \pm 0.105 \%)$ were similar to typical Wisconsin norms for dairy slurry (Laboski and Peters, 2012), whereas total N $(3.9 \pm 0.52 \%)$ and $\mathrm{K}$ $(4.1 \pm 0.92 \%)$ deviated from typical norms (4.49 and $3.11 \%$, respectively) by about the standard deviation of our measurement. Only concentrations of S in our dairy slurry $(0.30 \pm 0.026 \%)$ deviated sharply from those typically reported for Wisconsin dairy farms $(\sim 0.79 \%$; Laboski and Peters, 2012). The relatively large ash concentration $(36.1 \pm 6.56 \%)$ reflects the sand bedding used within freestalls by lactating cows at the 
Marshfield Agricultural Research Station. Clostridium tyrobutyricum was not detected in dairy slurry from any of the application dates; however, the overall mean count for Clostridium cluster 1 within our dairy slurry $\left(6.89 \pm 0.181 \log _{10}\right.$ genomic copies/g) is consistent with other reports that show dairy slurry to be a source of clostridia (Rammer et al., 1994, 1997; Davies et al., 1996) that may serve as a significant source of silage contamination in addition to that derived from the soil (McDonald et al., 1991). Some reports (Davies et al., 1996; Rammer et al., 1997) indicate these clostridia possess lactate-fermenting capability, but this was not specifically evaluated in our study.

\section{Pre-Ensiled Bale Characteristics and Nutritive Value}

$\boldsymbol{H A R V 1}$. The slurry application $\times$ initial bale moisture interaction was not significant $(P>0.05)$ for most initial bale characteristics; therefore, only main effects are presented (Table 2). Plots receiving no slurry exhibited greater yields of DM than slurry-applied plots; however, these differences were only numerical $(2,691$ vs. $2,406 \mathrm{~kg} / \mathrm{ha} ; P=0.193)$. Even though statistical differences in forage yield were not detected on the basis of slurry application treatments, some visual evidence of leaf burn was observed, particularly when slurry application was delayed by 1 or 2 wk following the previous harvest. This may have contributed to the numerical yield advantage observed for research plots receiving no dairy slurry. On a pre-ensiled basis, indices of nutritive value (Table 3) generally exhibited no interaction of main effects $(P>0.05)$. Although testing of preplanned contrasts yielded several statistically significant responses to treatment, most differences were of limited magnitude, and of somewhat questionable practical relevance. Specifically, concentrations of most fiber components were greater for forages receiving no dairy slurry compared with those receiving dairy slurry; specifically, these effects were observed for NDF (40.7 vs. $39.0 \% ; P=0.037), \mathrm{ADF}(31.4$ vs. $29.9 \% ; P$ $=0.032)$, cellulose $(24.5$ vs. $23.3 \% ; P=0.033)$, and lignin (6.30 vs. $5.88 \% ; P=0.018)$, but not for hemicellulose (overall mean $=9.2 \% ; P=0.683$ ). Conversely, concentrations of $\mathrm{CP}$ were reduced in forages receiving no slurry compared with those receiving slurry (19.1 vs. $20.2 \% ; P=0.017$ ), and a similar response was observed for TDN (60.0 vs. $61.1 \% ; P=0.010)$. Concentrations of cellulose were greater when dairy slurry was applied to alfalfa stubble compared with delayed applications of 1 or 2 wk $(24.2$ vs. $22.9 \% ; P=0.024)$, whereas the opposite response was observed for NDICP (2.54 vs. $2.91 \% ; P=0.017)$. No differences in nutritive value were detected for comparisons of slurry applications delayed for 1 versus 2 wk $(P \geq 0.147)$, nor were differences detected between ideal versus dry bale moistures $(P \geq 0.084)$.

$\boldsymbol{H A R V 2 . ~ S l u r r y ~ a p p l i c a t i o n ~ t r e a t m e n t s ~ y i e l d e d ~ n o ~}$ significant contrasts $(P \geq 0.080)$ for initial physical characteristics of bales produced in HARV2 (Table 4). Because of the drought conditions during late summer 2012, yields of DM from research plots (overall mean = $781 \mathrm{~kg} / \mathrm{ha} ; P \geq 0.229$ ) were reduced to approximately one-third of those observed for HARV1, and only 1 abbreviated bale (overall mean length $=0.89 \mathrm{~m} ; P \geq$

Table 2. Initial bale characteristics for second cutting alfalfa (HARV1) wrapped as balage following applications of dairy slurry onto stubble, or after 1 or 2 wk of regrowth at Stratford, Wisconsin, during 2012

\begin{tabular}{|c|c|c|c|c|c|c|c|c|}
\hline Treatment & $\begin{array}{c}\text { Bale } \\
\text { height }(\mathrm{m})\end{array}$ & $\begin{array}{c}\text { Bale } \\
\text { length }(\mathrm{m})\end{array}$ & $\begin{array}{c}\text { Bale } \\
\text { volume }\left(\mathrm{m}^{3}\right)\end{array}$ & $\begin{array}{l}\text { Wet bale } \\
\text { weight }(\mathrm{kg})\end{array}$ & $\begin{array}{c}\text { Bale } \\
\text { moisture (\%) }\end{array}$ & $\begin{array}{c}\text { Dry bale } \\
\text { weight } \\
\text { (kg of DM) }\end{array}$ & $\begin{array}{c}\text { DM bale } \\
\text { density } \\
\left(\mathrm{kg} \text { of } \mathrm{DM} / \mathrm{m}^{3}\right)\end{array}$ & $\begin{array}{c}\text { Plot yield }^{1} \\
\text { (kg/ha) }\end{array}$ \\
\hline \multicolumn{9}{|c|}{ Slurry application ${ }^{2}$} \\
\hline Stubble & 0.86 & 1.75 & 1.29 & 342 & 40.8 & 198 & 161 & 2,420 \\
\hline $1 \mathrm{wk}$ & 0.85 & 1.64 & 1.14 & 323 & 37.9 & 191 & 167 & 2,308 \\
\hline $2 \mathrm{wk}$ & 0.86 & 1.74 & 1.22 & 345 & 38.5 & 208 & 172 & 2,490 \\
\hline Ideal & 0.85 & 1.72 & 1.18 & 392 & 46.2 & 208 & 176 & - \\
\hline Dry & 0.86 & 1.85 & 1.30 & 305 & 34.5 & 194 & 150 & - \\
\hline SEM & 0.003 & 0.064 & 0.043 & 20.2 & 2.14 & 7.6 & 4.5 & - \\
\hline \multicolumn{9}{|c|}{ Contrasts $^{4}(P>F)$} \\
\hline $\mathrm{I}$ & 0.181 & 0.011 & 0.012 & 0.048 & 0.039 & 0.527 & 0.043 & 0.193 \\
\hline II & 0.423 & 0.545 & 0.434 & 0.733 & 0.273 & 0.905 & 0.267 & 0.924 \\
\hline III & 0.318 & 0.397 & 0.300 & 0.411 & 0.810 & 0.264 & 0.614 & 0.483 \\
\hline
\end{tabular}

${ }^{1}$ Yield determined by weighing all baled forage removed from each $14-\times 122-\mathrm{m}(0.17$-ha) plot and correcting for the moisture within each bale. ${ }^{2}$ Dairy slurry was applied to individual plots at a rate of $42,400 \pm 5,271 \mathrm{~L} / \mathrm{ha}$.

${ }^{3}$ Initial bale moisture: ideal $=46.2 \%$ and dry $=34.5 \%$.

${ }^{4}$ Contrasts: $\mathrm{I}=$ no slurry vs. slurry (stubble, $1 \mathrm{wk}$, or $2 \mathrm{wk}$ ); II = immediate slurry application (stubble) vs. delayed slurry application (1 or 2 wk); III = 1 wk regrowth vs. 2 wk regrowth; and IV = ideal vs. dry balage. 
Table 3. Pre-ensiled concentrations of fiber components, protein components, ash, and TDN for second cutting alfalfa (HARV1) wrapped as balage following applications of dairy slurry onto stubble, or after 1 or 2 wk of regrowth at Stratford, Wisconsin, during 2012

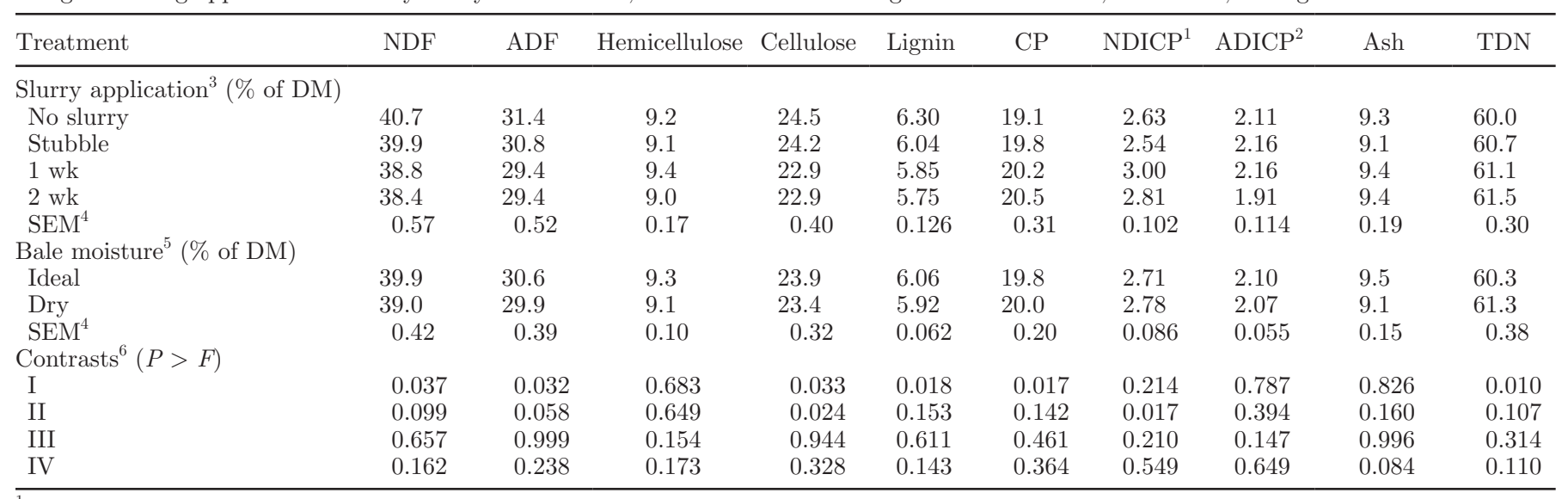

${ }^{1} \mathrm{NDICP}=$ neutral detergent-insoluble CP.

${ }^{2} \mathrm{ADICP}=$ acid detergent-insoluble CP.

${ }^{3}$ Dairy slurry was applied to individual plots at a rate of $42,400 \pm 5,271 \mathrm{~L} / \mathrm{ha}$.

${ }^{4} \mathrm{SEM}=$ standard error of the main-effect mean.

${ }^{5}$ Initial bale moisture: ideal $=46.2 \%$ and dry $=34.5 \%$.

${ }^{6}$ Contrasts: $\mathrm{I}=$ no slurry vs. slurry (stubble, $1 \mathrm{wk}$, or $2 \mathrm{wk}$ ); II = immediate slurry application (stubble) vs. delayed slurry application (1 or 2 wk); III = 1 wk regrowth vs. 2 wk regrowth; and IV = ideal vs. dry balage.

0.298) was produced per research plot at an ideal moisture concentration for balage (overall mean $=49.1 \% ; P$ $\geq 0.080)$. On a pre-ensiled basis, only minor differences in nutritive value were noted as a consequence of the various slurry application strategies (Table 5). Concentrations of NDF were greater when slurry applications were delayed by 1 or 2 wk compared with immediate application onto alfalfa stubble (38.2 vs. $35.7 \% ; P=$ 0.036 ), and $C P$ was greater when slurry application was delayed by 2 wk compared with only 1 wk (23.4 vs. $22.1 \% ; P=0.027)$. After considering all inputs required for a summative calculation of energy density (NRC, 2001), TDN was greater for control plots receiving no slurry compared with all slurry-applied plots (63.1 vs. $61.4 \% ; P=0.028)$. No other contrast comparing slurry application effects on measures of nutritive value was significant $(P \geq 0.060)$.

\section{Post-Ensiled Nutritive Value}

Few detectable effects of treatment on post-ensiled nutritive value were observed. As a result, only overall means are reported for nutritive indices obtained from bales produced from HARV1 and HARV2 (Table 6). For HARV1, no measure of nutritive value was affected $(P \geq 0.068)$ by slurry application strategy; however,

Table 4. Initial bale characteristics for third cutting alfalfa (HARV2) wrapped as balage following applications of dairy slurry onto stubble, or after 1 or 2 wk of regrowth at Stratford, Wisconsin, during 2012

\begin{tabular}{|c|c|c|c|c|c|c|c|c|}
\hline Treatment & $\begin{array}{c}\text { Bale } \\
\text { height }(\mathrm{m})\end{array}$ & $\begin{array}{c}\text { Bale } \\
\text { length }(\mathrm{m})\end{array}$ & $\begin{array}{c}\text { Bale } \\
\text { volume }\left(\mathrm{m}^{3}\right)\end{array}$ & $\begin{array}{c}\text { Wet bale } \\
\text { weight }(\mathrm{kg})\end{array}$ & $\begin{array}{c}\text { Bale } \\
\text { moisture (\%) }\end{array}$ & $\begin{array}{c}\text { Dry bale } \\
\text { weight } \\
\text { (kg of DM) }\end{array}$ & $\begin{array}{c}\text { DM bale } \\
\text { density } \\
\left(\mathrm{kg} \text { of } \mathrm{DM} / \mathrm{m}^{3}\right)\end{array}$ & $\begin{array}{c}\text { Plot } \\
\text { yield }^{1} \\
(\mathrm{~kg} / \mathrm{ha})\end{array}$ \\
\hline \multicolumn{9}{|c|}{ Slurry application ${ }^{2}$} \\
\hline Stubble & 0.88 & 0.92 & 0.67 & 279 & 52.9 & 130 & 196 & 780 \\
\hline $1 \mathrm{wk}$ & 0.87 & 0.96 & 0.69 & 284 & 48.5 & 146 & 210 & 872 \\
\hline 2 wk & 0.88 & 0.87 & 0.63 & 242 & 47.4 & 123 & 200 & 737 \\
\hline I & 0.394 & 0.298 & 0.263 & 0.188 & 0.422 & 0.494 & 0.767 & 0.495 \\
\hline II & 0.220 & 0.934 & 0.920 & 0.538 & 0.080 & 0.789 & 0.540 & 0.789 \\
\hline III & 0.490 & 0.413 & 0.444 & 0.177 & 0.734 & 0.228 & 0.551 & 0.229 \\
\hline
\end{tabular}

${ }^{1}$ Yield determined by weighing all baled forage removed from each $14-\times 122-\mathrm{m}$ (0.17-ha) plot and correcting for the moisture within each bale.

${ }^{2}$ Dairy slurry was applied to individual plots at a rate of $41,700 \pm 2,397 \mathrm{~L} / \mathrm{ha}$.

${ }^{3} \mathrm{SEM}=$ standard error of the main-effect mean.

${ }^{4}$ Contrasts: I = no slurry vs. slurry (stubble, $1 \mathrm{wk}$, or $\left.2 \mathrm{wk}\right) ; \mathrm{II}=$ immediate slurry application (stubble) vs. delayed slurry application (1 or 2 wk); and III = 1 wk regrowth vs. 2 wk regrowth. 
Table 5. Pre-ensiled concentrations of fiber components, CP components, ash, and TDN for third cutting alfalfa (HARV2) wrapped as balage following applications of dairy slurry onto stubble, or after 1 or 2 wk of regrowth at Stratford, Wisconsin, during 2012

\begin{tabular}{|c|c|c|c|c|c|c|c|c|c|c|}
\hline Treatment & $\mathrm{NDF}$ & $\mathrm{ADF}$ & Hemicellulose & Cellulose & Lignin & $\mathrm{CP}$ & $\mathrm{NDICP}^{1}$ & $\mathrm{ADICP}^{2}$ & Ash & TDN \\
\hline $1 \mathrm{wk}$ & 39.0 & 28.0 & 10.9 & 20.4 & 5.19 & 22.1 & 4.13 & 1.91 & 11.3 & 60.8 \\
\hline $2 \mathrm{wk}$ & 37.3 & 27.2 & 10.1 & 20.5 & 5.37 & 23.4 & 4.02 & 2.08 & 10.8 & 61.3 \\
\hline $\mathrm{SEM}^{4}$ & 0.83 & 0.70 & 0.40 & 0.99 & 0.34 & 0.34 & 0.246 & 0.124 & 0.82 & 0.56 \\
\hline \multicolumn{11}{|c|}{ Contrasts $^{5}(P>F)$} \\
\hline II & 0.036 & 0.128 & 0.060 & 0.724 & 0.625 & 0.580 & 0.109 & 0.606 & 0.882 & 0.133 \\
\hline III & 0.192 & 0.422 & 0.186 & 0.945 & 0.705 & 0.027 & 0.747 & 0.356 & 0.678 & 0.505 \\
\hline
\end{tabular}

${ }^{1} \mathrm{NDICP}=$ neutral detergent-insoluble CP.

${ }^{2} \mathrm{ADICP}=$ acid detergent-insoluble $\mathrm{CP}$.

${ }^{3}$ Dairy slurry was applied to individual plots at a rate of $41,700 \pm 2,397 \mathrm{~L} / \mathrm{ha}$.

${ }^{4} \mathrm{SEM}=$ standard error of the main-effect mean.

${ }^{5}$ Contrasts: $\mathrm{I}=$ no slurry vs. slurry (stubble, $1 \mathrm{wk}$, or $2 \mathrm{wk}$ ); II = immediate slurry application (stubble) vs. delayed slurry application (1 or 2 wk regrowth); and III $=1$ wk regrowth vs. 2 wk regrowth.

concentrations of NDICP were greater in dry balage compared with ideal balage (4.80 vs. $3.61 \% ; P=0.003$ ), but ADICP was not affected by initial bale moisture $(P$ $=0.939)$. For HARV2, only concentrations of CP were affected by slurry application; $\mathrm{CP}$ was greater in silage bales receiving slurry applied to stubble compared with those receiving slurry after a 1- or 2-wk delay (25.1 vs. $23.8 \% ; P=0.017$ ). No other contrast was significant $(P \geq 0.077)$. Averaged across both harvests, the mean poststorage recovery of DM from silage bales was $95.6 \pm 5.36 \%$. Although this represents reasonable recovery of DM following silage fermentation with this conservation technique, modest numerical increases in concentrations of most fiber components and $\mathrm{CP}$ were observed in fermented balage relative to pre-ensiled concentrations, particularly for bales produced from HARV1. Collectively, these changes resulted in modest overall reductions in TDN for fermented balage relative to pre-ensiled estimates for HARV1 (58.7 vs. 60.8\%), and to a lesser extent for HARV2 (60.6 vs. 61.9\%). Rotz and Muck (1994) have described effects of respiratory losses during fermentation, indicating losses of carbohydrates via respiration often result in measurable increases in fiber components and $\mathrm{CP}$, which collectively yields only modest reductions in TDN within well-managed silage fermentations. These losses of DM and energy are inconsistent with greater expectations for losses associated with clostridial fermentations (McDonald et al., 1991), thereby suggesting slurry application had little effect on recoveries of DM and TDN.

\section{Pre-Ensiled Indicators of Ensilability}

$\boldsymbol{H A R V 1}$. No slurry application $\times$ initial bale moisture interactions were observed for initial $\mathrm{pH}, \mathrm{BC}$,
WSC, or starch; therefore, only main effects are presented (Table 7) and discussed. The initial $\mathrm{pH}$ of alfalfa forages before bales were wrapped in plastic was not affected by slurry application $(P \geq 0.375)$ or initial bale moisture $(P=0.360)$, and exhibited an overall mean across all treatments of 6.06 , which is consistent with other work with pre-ensiled alfalfa (Muck, 1987; Kizilsimsek et al., 2007; Coblentz and Muck, 2012). Buffering capacity tended to be greater for forages receiving no slurry compared with slurry-applied forages (383 vs. $364 \mathrm{mEq} / \mathrm{kg} ; P=0.063$ ), and for ideal compared with dry forages (380 vs. $357 \mathrm{mEq} / \mathrm{kg} ; P=0.065)$. Concentrations of WSC and starch were not affected $(P \geq$ 0.099 ) by slurry application or initial bale moisture, although the overall concentration of WSC in pre-ensiled HARV1 forages $(7.2 \%)$ was greater than reported in other studies (Kiziksimsek et al., 2007; Schmidt et al., 2009; Kung et al., 2010), and may have been related to the drought conditions that became increasingly stressful for growing forage plants throughout the late July.

$\boldsymbol{H} \boldsymbol{A} \boldsymbol{R} \boldsymbol{V}$ 2. For HARV2, the overall effects of slurry application strategies on indicators of ensilability were minor (Table 7). The $\mathrm{pH}$ of alfalfa forages immediately before ensiling $(\mathrm{pH}=6.02)$ was comparable to that observed for HARV1, and was not affected $(P \geq 0.266)$ by slurry application treatments. Similarly, BC was not affected by slurry treatment $(P \geq 0.083)$, but the improved nutritive value for HARV2 forages relative to HARV1 suggests a greater proportion of leaf tissue was present in the forage mass (Muck and Walgenbach, 1985), and this is reflected in a greater overall $\mathrm{BC}$ for HARV2 (overall mean $=438 \mathrm{mEq} / \mathrm{kg}$ ). Concentrations of WSC were greater for pre-ensiled alfalfa without slurry compared with forages receiving dairy slurry $(6.0$ vs. $5.4 \% ; P=0.037)$, but no other significant contrast 
Table 6. Post-ensiled concentrations of fiber components, CP components, ash, and TDN for second (HARV1) and third cutting (HARV2) alfalfa wrapped as balage following applications of dairy slurry onto stubble, or after 1 or 2 wk of regrowth at Stratford, Wisconsin, during $2012^{1}$

\begin{tabular}{|c|c|c|c|c|c|c|c|c|c|c|}
\hline $\begin{array}{l}\text { Treatment } \\
(\% \text { of } \mathrm{DM})\end{array}$ & $\mathrm{NDF}$ & $\mathrm{ADF}$ & Hemicellulose & Cellulose & Lignin & $\mathrm{CP}$ & $\mathrm{NDICP}^{2}$ & $\mathrm{ADICP}^{3}$ & Ash & TDN \\
\hline \multicolumn{11}{|l|}{ HARV $1^{4}$} \\
\hline \multicolumn{11}{|l|}{ HARV $2^{6}$} \\
\hline Overall mean & 38.1 & 26.2 & 11.8 & 19.4 & 5.66 & 24.1 & 3.24 & 1.82 & 11.0 & 60.6 \\
\hline $\mathrm{SEM}^{7}$ & 0.69 & 0.65 & 0.23 & 0.45 & 0.139 & 0.17 & 0.106 & 0.101 & 0.22 & 0.63 \\
\hline
\end{tabular}

${ }^{1}$ Post-ensiled assessment of nutritive value was largely unaffected by treatment, and only the overall means and SEM are presented.

${ }^{2} \mathrm{NDICP}=$ neutral detergent-insoluble $\mathrm{CP}$.

${ }^{3} \mathrm{ADICP}=$ acid detergent-insoluble $\mathrm{CP}$.

${ }^{4}$ Dairy slurry was applied to individual plots at a rate of $42,400 \pm 5,271 \mathrm{~L} / \mathrm{ha}$.

${ }^{5} \mathrm{SEM}=$ standard error of the overall mean $(\mathrm{n}=33$ bales $)$.

${ }^{6}$ Dairy slurry was applied to individual plots at a rate of $41,700 \pm 2,397 \mathrm{~L} / \mathrm{ha}$.

${ }^{7} \mathrm{n}=16$ bales.

was detected $(P \geq 0.481)$. Pre-ensiled concentrations of starch were not affected by slurry application strategies (overall mean $=1.57 \% ; P \geq 0.249$ ).

\section{Silage Fermentation}

$\boldsymbol{H A R V 1}$. The slurry application treatment $\times$ bale moisture interaction was not significant $(P \geq 0.195)$ for final bale moisture, $\mathrm{pH}$, and concentrations of WSC and starch; therefore, only main effects are presented (Table 8) and discussed. Slurry application treatments had no effect $(P \geq 0.066)$ on these response variables.
After storage, ideal bales exhibited greater concentrations of moisture than dry bales (46.8 vs. $39.9 \%$; $P=$ 0.044 ), and this was reflected by a slightly more acidic final $\mathrm{pH}$ within ideal silages (5.54 vs. 5.61; $P=0.008$ ) Final concentrations of WSC $(5.9 \% ; P=0.473)$ and starch $(0.67 \% ; P=0.571)$ did not differ between ideal and dry balage. The relatively high final $\mathrm{pH}$ for alfalfa balage from HARV1 (overall mean $=5.58$ ) is primarily related to 2 factors. First, Muck (1990) demonstrated that final silage $\mathrm{pH}$ and moisture content are inversely related for alfalfa; on that basis, the drier forage ensiled in HARV1 would be expected to exhibit a greater

Table 7. Pre-ensiled forage $\mathrm{pH}$, buffering capacity (BC), water-soluble carbohydrates (WSC), and starch for second (HARV1) and third (HARV2) cutting alfalfa wrapped as balage following applications of dairy slurry onto stubble, or after 1 or 2 wk of regrowth at Stratford, Wisconsin, during 2012

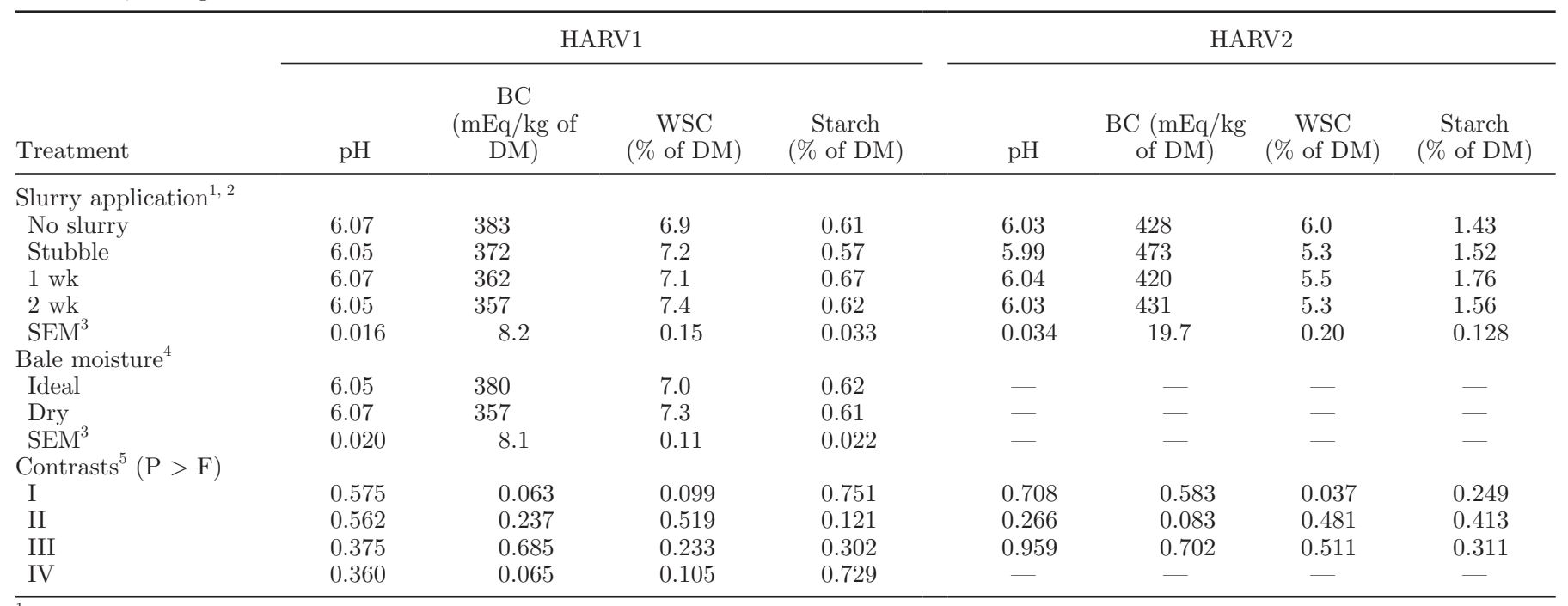

${ }^{1}$ For HARV1, dairy slurry was applied to individual plots at a rate of $42,400 \pm 5,271 \mathrm{~L} / \mathrm{ha}$.

${ }^{2}$ For HARV2, dairy slurry was applied to individual plots at a rate of $41,700 \pm 2,397 \mathrm{~L} / \mathrm{ha}$.

${ }^{3} \mathrm{SEM}=$ standard error of the main-effect mean.

${ }^{4}$ Initial bale moistures for HARV1 were ideal $=46.2 \%$ and dry $=34.5 \%$.

${ }^{5}$ Contrasts: I = no slurry vs. slurry (stubble, $1 \mathrm{wk}$, or $2 \mathrm{wk}$ ); II = immediate slurry application (stubble) vs. delayed slurry application (1 or 2 wk regrowth); III = 1 wk regrowth vs. 2 wk regrowth; and IV = ideal vs. dry balage. 
final $\mathrm{pH}$ than precision-chopped alfalfa forages ensiled at $>60 \%$ moisture, which often reach a final $\mathrm{pH}<5.0$. Second, the alfalfa forage baled within these studies underwent no particle size reduction via maceration or cutting knives within the baler; therefore, WSC were likely released slowly, thereby slowing the proliferation of lactic acid-producing bacteria and limiting silage fermentation rate (Nicholson et al., 1991; Muck et al., 2003; Savoie and Jofriet, 2003). Even at relatively high moisture concentrations for balage $(\sim 65 \%)$, McCormick et al. (1998) observed tendencies for a greater final $\mathrm{pH}$ and reduced production of lactic acid in annual ryegrass (Lolium multiflorum L.) preserved as balage compared with precision-chopped ryegrass ensiled from the same forage source.

The relatively high final $\mathrm{pH}$ for these silages suggests limited production of silage fermentation acids, which was confirmed by the final concentrations of lactic $(0.21 \%$ of DM; Table 9$)$ and acetic $(0.20 \%$ of DM) acids, neither of which were affected by manure treatment $(P \geq 0.799)$, bale moisture $(P \geq 0.806)$, or the interaction of these main effects $(P \geq 0.225)$. Generally, production of lactic acid in silages from HARV1 was minimal or undetectable in bales with an initial bale moisture $<45 \%(0.02 \pm 0.057 \%$ of DM), but increased for wetter $(>45 \%)$ bales $(0.57 \pm 0.578 \%$ of DM). Whereas studies conducted with alfalfa balage in Kentucky (Han et al., 2004; Hancock and Collins, 2006) have reported greater lactic acid production than observed for HARV1, other studies with grasses baled at $<50 \%$ moisture (Rhein et al., 2005; Borreani et al., 2007) have reported concentrations of lactic acid ranging from 0.57 to $1.20 \%$ of $\mathrm{DM}$ with a corresponding final $\mathrm{pH} \geq 5.13$. No significant effects of treatment were observed for any other measured fermentation product $(P \geq 0.182)$. Normal end products of clostridial fermentations, such as butyric acid and $\mathrm{NH}_{3}-\mathrm{N}$, exhibited minimal final concentrations $(0.05 \%$ of $\mathrm{DM}$ and $1.80 \%$ of total $\mathrm{N}$, respectively), thereby suggesting a minimal effect of clostridia on the preservation of these silages.

$\boldsymbol{H A R V 2 . ~ F i n a l ~ b a l e ~ m o i s t u r e ~ ( T a b l e ~ 8 ) ~ d i d ~ n o t ~ v a r y ~}$ across slurry application treatments (overall mean = $50.6 \% ; P \geq 0.526$ ), nor did final $\mathrm{pH}$ (overall mean $=$ $5.42 ; P \geq 0.536)$, WSC $(3.7 \% ; P \geq 0.527)$ or starch $(1.56 \% ; P \geq 0.073)$. The main effect of slurry application treatment was not significant $(P \geq 0.066)$ for any measured fermentation product; therefore, data for these response variables are summarized only as overall means (Table 9). However, the modest increase in bale moisture for HARV2 relative to HARV1 yielded a greater overall production of lactic acid (1.43 vs. $0.21 \%$ of $\mathrm{DM})$ and a slightly more acidic overall final $\mathrm{pH}$ across all bales (5.42 vs. 5.58).

\section{Enumeration of Clostridia}

$\boldsymbol{H A R V 1 . ~ C l o s t r i d i u m ~ t y r o b u t y r i c u m ~ w a s ~ n o t ~ d e t e c t - ~}$ ed in any of the forage samples obtained before or after

Table 8. Final moisture concentrations, silage pH, water-soluble carbohydrates (WSC), and starch for second (HARV1) and third (HARV2) cutting alfalfa wrapped as balage following applications of dairy slurry onto stubble, or after 1 or 2 wk of regrowth at Stratford, Wisconsin, during 2012; final sampling of silages occurred from May 29 to 31, 2013

\begin{tabular}{|c|c|c|c|c|c|c|c|c|}
\hline Treatment & \multicolumn{4}{|c|}{ HARV1 } & \multicolumn{4}{|c|}{ HARV2 } \\
\hline No slurry & 43.6 & 5.58 & 6.1 & 0.66 & 49.9 & 5.40 & 3.5 & 1.60 \\
\hline Stubble & 41.9 & 5.57 & 6.1 & 0.59 & 50.0 & 5.46 & 4.0 & 1.61 \\
\hline $1 \mathrm{wk}$ & 42.9 & 5.61 & 5.8 & 0.78 & 50.4 & 5.36 & 3.8 & 1.72 \\
\hline Ideal & 46.8 & 5.54 & 6.0 & 0.68 & - & - & - & - \\
\hline Dry & 39.9 & 5.61 & 5.8 & 0.66 & - & - & - & - \\
\hline $\mathrm{SEM}^{3}$ & 2.16 & 0.015 & 0.21 & 0.033 & - & - & - & - \\
\hline \multicolumn{9}{|c|}{ Contrasts $^{5}(P>F)$} \\
\hline I & 0.890 & 0.999 & 0.518 & 0.797 & 0.645 & 0.812 & 0.558 & 0.752 \\
\hline II & 0.465 & 0.602 & 0.311 & 0.066 & 0.589 & 0.599 & 0.527 & 0.611 \\
\hline
\end{tabular}

${ }^{1}$ For HARV1, dairy slurry was applied to individual plots at a rate of $42,400 \pm 5,271 \mathrm{~L} / \mathrm{ha}$.

${ }^{2}$ For HARV2, dairy slurry was applied to individual plots at a rate of 41,700 $\pm 2,397 \mathrm{~L} / \mathrm{ha}$.

${ }^{3} \mathrm{SEM}=$ standard error of the main-effect mean.

${ }^{4}$ Initial bale moistures for HARV1 were ideal $=46.2 \%$; and dry $=34.5 \%$.

${ }^{5}$ Contrasts: I = no slurry vs. slurry (stubble, $1 \mathrm{wk}$, or $2 \mathrm{wk}$ ); II = immediate slurry application (stubble) vs. delayed slurry application (1 or 2 wk regrowth); III = 1 wk regrowth vs. 2 wk regrowth; and IV = ideal vs. dry balage. 
Table 9. Concentrations of fermentation acids, ethanol, 2,3-butanediol, and $\mathrm{NH}_{3}-\mathrm{N}$ for second (HARV1) and third cutting alfalfa (HARV2) wrapped as balage following applications of dairy slurry onto stubble, or after 1 or 2 wk of regrowth at Stratford, Wisconsin, during $2012^{1}$

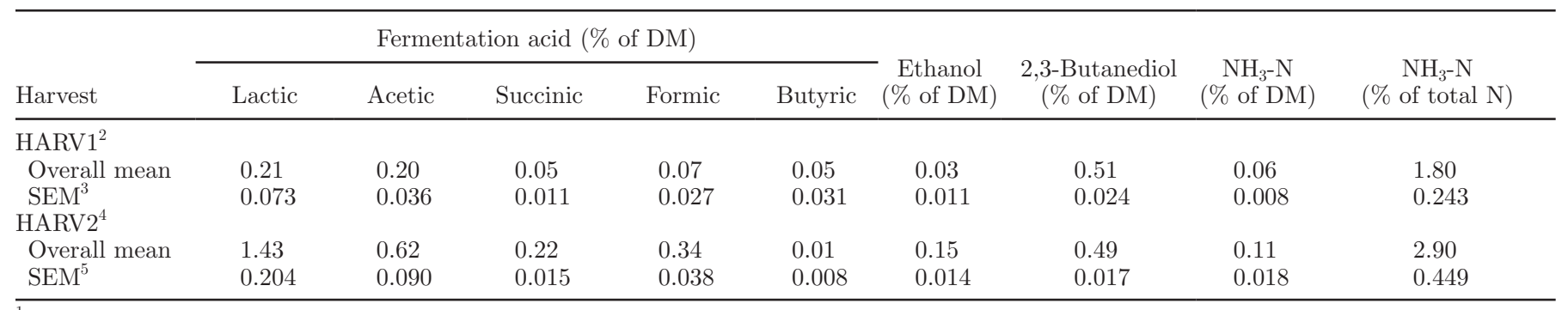

${ }^{1}$ Fermentation products were unaffected by treatment, and only overall means from each harvest are presented; propionic acid and 1,2-propanediol also were evaluated, but mean concentrations were $\leq 0.01 \%$ of DM.

${ }^{2}$ Dairy slurry was applied to individual plots at a rate of $42,400 \pm 5,271 \mathrm{~L} / \mathrm{ha}$.

${ }^{3} \mathrm{SEM}=$ standard error of the overall mean ( $\mathrm{n}=33$ bales $)$.

${ }^{4}$ Dairy slurry was applied to individual plots at a rate of $41,700 \pm 2,397 \mathrm{~L} / \mathrm{ha}$.

${ }^{5} \mathrm{n}=16$ bales.

ensiling (Table 10). Pre-ensiled counts for Clostridium cluster 1 were greater for forages harvested following slurry application compared with no slurry (4.44 vs. $3.29 \log _{10}$ genomic copies/g; $P=0.002$ ), which is consistent with other work (Davies et al., 1996) with perennial ryegrass (Lolium perenne L.). A trend for greater clostridial counts in forages receiving delayed slurry applications compared with slurry applied directly to alfalfa stubble was also observed (4.62 vs. $4.10 \log _{10}$ genomic copies $/ g ; P=0.061)$. No differences in clostridial counts associated with a 1 - versus 2 -wk slurry application delay were noted $(P=0.363)$, nor were counts affected by initial bale moisture $(P=0.247)$. Following silage fermentation, similar responses were observed; bales produced from plots receiving slurry exhibited greater counts than bales from control plots receiving no slurry (5.40 vs. $4.26 \log _{10}$ genomic copies/g; $P<$ 0.001 ), and counts following delayed slurry applications were greater than those from bales with slurry applied to stubble (5.51 vs. $5.17 \log _{10}$ genomic copies/g; $P=$ 0.018). Although not compared statistically, overall raw clostridial counts were greater following fermentation by a factor of about 10 relative to counts obtained from pre-ensiled forages (5.11 vs. $4.16 \log _{10}$ genomic copies $/ \mathrm{g})$.

$\boldsymbol{H A R V 2 . ~ O n ~ a ~ p r e - e n s i l e d ~ b a s i s , ~ c l o s t r i d i a l ~ c o u n t s ~}$ for forages receiving slurry were greater than those observed for control plots receiving no slurry (4.99 vs. 3.88 $\log _{10}$ genomic copies/g; $P<0.001$; Table 10). No differences were observed among slurry-applied treatments based on the timing of application $(P \geq 0.432)$. Following silage fermentation, strong slurry effects were noted on clostridial counts. Slurry-applied silages differed from control silages receiving no slurry ( 5.65 vs. 4.21 $\log _{10}$ genomic copies/g; $\left.P<0.001\right)$. Strong differences $(P<0.001)$ also were observed for contrasts evaluating the timing of slurry application. Clostridial counts were related positively to time delays associated with slurry applications, which is consistent with other work (Davies et al., 1996). As observed for HARV1, overall mean clostridial counts following silage fermentation were numerically greater than those observed for preensiled forages (5.29 vs. $4.71 \log _{10}$ genomic copies/g).

\section{Overall Management Implications}

Clostridial counts obtained on a pre- and post-ensiled basis suggest an increased risk for undesirable clostridial fermentations within alfalfa silages following any application of dairy slurry, regardless of timing. For both HARV1 and HARV2, silages receiving dairy slurry that was applied to stubble exhibited greater $(P \leq 0.002)$ clostridial counts than silages receiving no slurry, and this was true on both a pre- and post-ensiled basis (Table 10). The effects of delaying applications of dairy slurry until alfalfa was actively growing were not as well defined. On a pre-ensiled basis, only a tendency for clostridial counts to be greater $(P=0.061)$ was observed within HARV1 forages receiving delayed applications of slurry relative to applications onto stubble, and no effect $(P=0.627)$ of application delay was observed for HARV2. For silages, delaying applications of dairy slurry for HARV1 and HARV2 resulted in greater $(P$ $\leq 0.018$ ) clostridial counts than applications of dairy slurry onto stubble. Furthermore, counts were increased with a 2-wk application delay compared with only 1 wk for HARV2 $(P<0.001)$, but this contrast was not detected for HARV1 $(P=0.176)$. Although these counts indicate increased abundance of clostridia and heightened risks of undesirable fermentations following applications of dairy slurry, no evidence suggested that clostridial counts affected preservation of these silages negatively. Generally, visual and olfactory evaluations of silages yielded no indication of traditional clostridial 
Table 10. Pre- and poststorage enumeration of Clostridium cluster 1 for second and third cutting alfalfa (HARV1 and HARV2) wrapped as balage following applications of dairy slurry onto stubble, or after 1 or $2 \mathrm{wk}$ of regrowth at Stratford, Wisconsin, during $2012^{1}$

\begin{tabular}{|c|c|c|c|c|}
\hline \multirow{2}{*}{$\begin{array}{l}\text { Treatment } \\
\left(\log _{10} \text { of genomic copies/g) }\right.\end{array}$} & \multicolumn{2}{|c|}{ Pre-ensiled } & \multicolumn{2}{|c|}{ Post-ensiled } \\
\hline & HARV1 & HARV2 & HARV1 & HARV2 \\
\hline \multicolumn{5}{|l|}{ Slurry application ${ }^{2,3}$} \\
\hline No slurry & 3.29 & 3.88 & 4.26 & 4.21 \\
\hline Stubble & 4.10 & 5.06 & 5.17 & 5.28 \\
\hline $1 \mathrm{wk}$ & 4.48 & 4.85 & 5.41 & 5.45 \\
\hline $2 \mathrm{wk}$ & 4.75 & 5.06 & 5.61 & 6.23 \\
\hline $\mathrm{SEM}^{4}$ & 0.198 & 0.178 & 0.095 & 0.074 \\
\hline \multicolumn{5}{|l|}{ Bale moisture $^{5}$} \\
\hline Ideal & 4.25 & - & 5.19 & - \\
\hline Dry & 4.07 & - & 5.04 & - \\
\hline $\mathrm{SEM}^{4}$ & 0.110 & - & 0.065 & - \\
\hline \multicolumn{5}{|l|}{ Contrasts $^{6}$} \\
\hline I & 0.002 & $<0.001$ & $<0.001$ & $<0.001$ \\
\hline II & 0.061 & 0.627 & 0.018 & $<0.001$ \\
\hline III & 0.363 & 0.432 & 0.176 & $<0.001$ \\
\hline IV & 0.247 & - & 0.133 & - \\
\hline
\end{tabular}

${ }^{1}$ Clostridium tyrobutyricum was not detected in any silage (pre- or poststorage basis); data represent Clostridium cluster 1.

${ }^{2}$ For HARV1, dairy slurry was applied to individual plots at a rate of $42,400 \pm 5,271 \mathrm{~L} / \mathrm{ha}$; pre- and poststorage sampling dates were 11 July 2012 and 29 May 2013, respectively.

${ }^{3}$ For HARV2, dairy slurry was applied to individual plots at a rate of $41,700 \pm 2,397 \mathrm{~L} / \mathrm{ha}$; pre- and poststorage sampling dates were August 11, 2012, and May 31, 2013, respectively.

${ }^{4} \mathrm{SEM}=$ standard error of the main-effect mean.

${ }^{5}$ Initial bale moistures for HARV1 were ideal $=46.2 \%$ and dry $=34.5 \%$.

${ }^{6}$ Contrasts: $\mathrm{I}=$ no slurry vs. slurry (stubble, $1 \mathrm{wk}$, or $2 \mathrm{wk}$ ); II = immediate slurry application (stubble) vs. delayed slurry application ( 1 or 2 wk regrowth); III $=1$ wk regrowth vs. 2 wk regrowth; and IV = ideal vs. dry balage.

end products. In addition, only minimal differences were noted among silage treatments with respect to traditional measures of nutritive value, and concentrations of fermentation acids and $\mathrm{NH}_{3}-\mathrm{N}$ were not consistent with expectations for clostridial silages. In part, this may be explained on the basis of our trial management, which included utilization of wrapped balage. Typical recommendations for moisture concentrations within baled silages range from 45 to $55 \%$ (Shinners, 2003), which is somewhat drier than recommendations for many precision-chopped alfalfa silages $(\leq 70 \%$; Muck et al., 2003). Because of the well-known difficulties inherent within alfalfa that make silage fermentation problematic, such as low concentrations of WSC and high buffering capacity, reducing forage moisture via field wilting is recommended routinely to ensure against clostridial fermentations (Pitt, 1990; Albrecht and Beauchemin, 2003; Muck et al., 2003). Although there was no direct comparison to wetter silages within our study, it would seem prudent from the standpoint of general silage management whenever dairy slurry has been applied to alfalfa stubble or regrowth to (1) use a silage inoculant that supports production of lactic acid, and (2) generally allow for some additional field desiccation, relative to traditional recommendations for precision-chopped silages.

The design of this research trial was not intended to assess the effects of wheel traffic, salt or ammonium burn, or physical smothering from excessive slurry application rates on the longer-term survival and productivity of alfalfa stands. However, cautions against these potential problems are well documented (Lory et al., 2000; Ketterings et al., 2006; Rankin, 2006), especially when slurry is applied after alfalfa regrowth has been initiated. Although silage quality generally was not affected by slurry applications onto actively growing alfalfa (poststubble), our visual observation of plots following delayed applications would suggest this option should only be considered as a last resort, such as when manure-storage reservoirs are full. Based on these (nonsilage) considerations, it is preferable to apply dairy slurry only to alfalfa stubble immediately after harvest. Should applications of dairy slurry onto growing alfalfa be necessary, producers might be well advised to select application sites on old alfalfa stands, rather than risk damage to recently established plants, thereby potentially reducing their productive life. 


\section{ACKNOWLEDGMENTS}

The authors gratefully acknowledge the generous financial support of the Midwest Forage Association (St. Paul, MN) in completing this project.

\section{REFERENCES}

Albrecht, K. A., and K. A. Beauchemin. 2003. Alfalfa and other perennial legume silage. Pages 633-664 in Silage Science and Technology. D. R. Buxton, R. E. Muck, and J. H. Harrison, ed. American Society of Agronomy, Crop Science Society of America, and Soil Science Society of America, Madison, WI.

AOAC International. 1998. Official Methods of Analysis. 16th ed. 4th rev. AOAC International, Gaithersburg, MD.

Borchardt, M. A., S. K. Spencer, B. A. Kieke Jr., E. Lambertini, and F. J. Loge. 2012. Viruses in non-disinfected drinking water from municipal wells and community incidence of acute gastrointestinal illness. Environ. Health Perspect. 120:1272-1279.

Borreani, G., D. Giaccone, A. Mimosi, and E. Tabacco. 2007. Comparison of hay and haylage from permanent alpine meadows in winter dairy cow diets. J. Dairy Sci. 90:5643-5650.

Broderick, G. A., P. Uden, M. L. Murphy, and A. Lapins. 2004. Sources of variation in rates of in vitro ruminal protein degradation. J. Dairy Sci. 87:1345-1359.

Buxton, D. R., and P. O'Kiely. 2003. Preharvest plant factors affecting ensiling. Pages 199-250 in Silage Science and Technology. D. R. Buxton, R. E. Muck, and J. H. Harrison, ed. American Society of Agronomy, Crop Science Society of America, and Soil Science Society of America, Madison, WI.

Coblentz, W. K., and R. E. Muck. 2012. Effects of natural and simulated rainfall on indicators of ensilability and nutritive value for wilting alfalfa forages sampled before preservation as silage. J. Dairy Sci. 95:6635-6653.

Collins, M. D., P. A. Lawson, A. Willems, J. J. Cordoba, J. FernandezGarayzabal, P. Garcia, J. Cai, H. Hippe, and J. A. E. Farrow. 1994. The phylogeny of the genus Clostridium: Proposal of five new genera and eleven new species combinations. Int. J. Syst. Bacteriol. 44:812-826.

Davies, D. R., R. J. Merry, and E. L. Bakewell. 1996. The effect of timing of slurry application on the microflora of grass, and changes occurring during silage fermentation. Grass Forage Sci. 51:42-51.

Dubois, M., K. A. Gilles, J. K. Hamilton, P. A. Rebers, and F. Smith 1956. Colorimetric method for determination of sugars and related substances. Anal. Chem. 28:350-356.

Gibson, K. E., K. J. Schwab, S. K. Spencer, and M. A. Borchardt. 2012. Measuring and mitigating inhibition during quantitative real time PCR analysis of viral nucleic acid extracts from large-volume environmental water samples. Water Res. 46:4281-4291.

Han, K. J., M. Collins, E. S. Vanzant, and C. T. Dougherty. 2004. Bale density and moisture effects on alfalfa round bale silage. Crop Sci. 44:914-919.

Hancock, D. W., and M. Collins. 2006. Forage preservation method influences alfalfa nutritive value and feeding characteristics. Crop Sci. 46:688-694.

Hedtcke, J. L., J. L. Posner, W. K. Coblentz, J. Hall, R. P. Walgenbach, and J. A. Davidson. 2011. Orchardgrass ley for improved manure management in Wisconsin: II. Nutritive value and voluntary intake by dairy heifers. Agron. J. 103:1106-1114.

Ketterings, Q. M., E. Frenay, J. H. Cherney, K. Czymmek, S. D. Klausner, L. E. Chase, and Y. H. Schukken. 2007. Application of manure to established stands of alfalfa and alfalfa-grass. Forage and Grazinglands 5:1. http://dx.doi.org/10.1094/FG-2007-041801-RV.

Ketterings, Q. M., E. Frenay, J. H. Cherney, K. J. Czymmek, S. D. Klausner, L. E. Chase, and Y. Schukken. 2006. Application of manure to established alfalfa. Agronomy Fact Sheet Series. Fact Sheet \#16. Cornell University Cooperative Extension, Ithaca, NY.
Kizilsimsek, M., R. J. Schmidt, and L. Kung Jr. 2007. Effects of a mixture of lactic acid bacteria applied as a freeze-died or fresh culture on the fermentation of alfalfa silage. J. Dairy Sci. 90:5698-5705. .

Kung, L., Jr., E. C. Stough, E. E. McDonell, R. J. Schmidt, M. W. Hofherr, L. J. Reich, and C. M. Klingerman. 2010. The effect of wide swathing on wilting times and nutritive value of alfalfa haylage. J. Dairy Sci. 93:1770-1773.

Laboski, C. A. M., and J. B. Peters. 2012. Nutrient application guidelines for field, vegetable, and fruit crops in Wisconsin. Miscellaneous Publication \#A2809. University of Wisconsin Cooperative Extension, Madison.

Lamb, J. F. S., M. P. Russelle, and M. A. Schmitt. 2005. Alfalfa and reed canarygrass response to midsummer manure application. Crop Sci. 45:2293-2300.

López-Enríquez, L., D. Rodriguez-Lazaro, and M. Hernandez. 2007. Quantitative detection of Clostridium tyrobutricum in milk by realtime PCR. Appl. Environ. Microbiol. 73:3747-3751.

Lory, J. A., R. L. Kallenbach, and C. A. Roberts. 2000. Managing manure on alfalfa hay. \#G4555. University of Missouri Cooperative Extension, Columbia.

McCormick, M. E., G. J. Cuomo, and D. C. Blouin. 1998. Annual ryegrass stored as balage, haylage, or hay for lactating dairy cows. J. Prod. Agric. 11:293-300.

McDonald, P., A. R. Henderson, and S. J. E. Heron. 1991. The Biochemistry of Silage. 2nd ed. Chalcombe Publications, Marlow, Buckinghamshire, UK.

Muck, R. E. 1987. Dry matter level effects on alfalfa silage quality. I. Nitrogen transformations. Trans. ASAE 30:7-14.

Muck, R. E. 1988. Factors influencing silage quality and their implications for management. J. Dairy Sci. 71:2992-3002.

Muck, R. E. 1990. Dry matter level effects on alfalfa silage quality. II. Fermentation products and starch hydrolysis. Trans. ASAE 33:373-381.

Muck, R. E., and J. T. Dickerson. 1988. Storage-temperature effects on proteolysis in alfalfa silage. Trans. ASAE 31:1005-1009.

Muck, R. E., L. E. Moser, and R. E. Pitt. 2003. Postharvest factors affecting ensiling. Pages 251-304 in Silage Science and Technology. D. R. Buxton, R. E. Muck, and J. H. Harrison, ed. American Society of Agronomy, Crop Science Society of America, and Soil Science Society of America, Madison, WI.

Muck, R. E., and R. P. Walgenbach. 1985. Variations in alfalfa buffering capacity. ASAE Paper No. 85-1535. Am. Soc. Agric. Eng., St. Joseph, MI.

Nicholson, J. W. G., R. E. McQueen, E. Charmley, and R. S. Bush. 1991. Forage conservation in round bales or silage: effect on ensiling characteristics and animal performance. Can. J. Anim. Sci. 71:1167-1180.

NOAA (National Oceanic and Atmospheric Administration). 2002. Monthly station normals of temperature, precipitation, and heating and cooling degree days 1971-2000. Climatography of the United States No. 81. 47 Wisconsin. National Climatic Data Center, National Environmental Satellite, Data, and Information Service, NOAA, Asheville, NC.

NRC. 2001. Nutrient Requirements of Dairy Cattle. 7th rev. ed. Natl. Acad. Press, Washington, DC.

Pahlow, G., R. E. Muck, F. Driehuis, S. J. W. H. Oude Elferink, and S. F. Spoelstra. 2003. Microbiology of ensiling. Pages 31-94 in Silage Science and Technology. D. R. Buxton, R. E. Muck, and J. H. Harrison, ed. American Society of Agronomy, Crop Science Society of America, and Soil Science Society of America, Madison, WI.

Pitt, R. E. 1990. Silage and hay preservation. Northeast Regional Agricultural Engineering Service. \#NRAES-5. NRAES Cooperative Extension, Ithaca, NY.

Rammer, C., C. Östling, P. Lingvall, and S. Lindgren. 1994. Ensiling of manured crops-Effects on fermentation. Grass Forage Sci. 49:343-351.

Rammer, C., and P. Lingvall. 1997. Influence of farmyard manure on the quality of grass silage. J. Sci. Food Agric. 75:133-140. 
Rammer, C., P. Lingvall, and E. Salomon. 1997. Ensiling of manured crops-Does repeated spreading of slurry increase the hygienic risk? J. Sci. Food Agric. 73:329-336.

Rankin, M. 2006. Applying manure to alfalfa. Focus on Forage. Vol. 8: No. 2. University of Wisconsin Cooperative Extension, Madison.

Rhein, R. T., W. K. Coblentz, J. E. Turner, C. F. Rosenkrans Jr., R K. Ogden, and D. W. Kellogg. 2005. Aerobic stability of wheat and orchardgrass round-bale silages during winter. J. Dairy Sci. $88: 1815-1826$.

Rooke, J. A., and R. D. Hatfield. 2003. Biochemistry of ensiling. Pages 95-140 in Silage Science and Technology. D. R. Buxton, R. E. Muck, and J. H. Harrison, ed. American Society of Agronomy, Crop Science Society of America, and Soil Science Society of America, Madison, WI.

Rotz, C. A., and R. E. Muck. 1994. Changes in forage quality during harvest and storage. Pages 828-868 in Forage Quality, Evaluation, and Utilization. G.C. Fahey, ed. Proc. Natl. Conf. on Forage Quality, Evaluation, and Utilization, Lincoln NE. Apr. 13-15, 1994. American Society of Agronomy, Crop Science Society of America, and Soil Science Society of America, Madison, WI.

Rotz, C. A., F. Taube, M. P. Russelle, J. Oenema, M. A. Sanderson, and M. Wachendorf. 2005. Whole-farm perspectives of nutrient flows in grassland agriculture. Crop Sci. 45:2139-2159.

Rutledge, R. G., and D. Stewart. 2010. Assessing the performance capabilities of LRE-based assays for absolute quantitative real-time PCR. PLoS ONE 5:e9731.

SAS Institute. 2002. Version 9.2. SAS Institute Inc., Cary, NC.

Savoie, P., and J. C. Jofriet. 2003. Silage storage. Pages 405-468 in Silage Science and Technology. D. R. Buxton, R. E. Muck, and J. H.
Harrison, ed. American Society of Agronomy, Crop Science Society of America, and Soil Science Society of America, Madison, WI.

Schmidt, R. J., W. Hu, J. A. Mills, and L. Kung Jr. 2009. The development of lactic acid bacteria and Lactobacillus buchneri and their effects on the fermentation of alfalfa silage. J. Dairy Sci. 92:5005-5010.

Shinners, K. J. 2003. Engineering principles of silage harvesting management. Pages 361-404 in Silage Science and Technology. D. R. Buxton, R. E. Muck, and J. H. Harrison, ed. American Society of Agronomy, Crop Science Society of America, and Soil Science Society of America, Madison, WI.

Song, Y., C. Liu, and S. M. Finegold. 2004. Real-Time PCR quantitation of clostridia in feces of autistic children. Appl. Environ. Microbiol. 70:6459-6465.

Van Soest, P. J., J. B. Robertson, and B. A. Lewis. 1991. Methods for dietary fiber, neutral detergent fiber, and nonstarch polysaccharides in relation to animal nutrition. J. Dairy Sci. 74:3583-3597.

Weiss, W. P., D. G. Chamberlain, and C. W. Hunt. 2003. Feeding silages. Pages 469-504 in Silage Science and Technology. D. R. Buxton, R. E. Muck, and J. H. Harrison, ed. American Society of Agronomy, Crop Science Society of America, and Soil Science Society of America, Madison, WI.

Weiss, W. P., H. R. Conrad, and N. R. Pierre. 1992. A theoreticallybased model for predicting total digestible nutrient values of forages and concentrates. Anim. Feed Sci. Technol. 39:95-110.

YSI. 2000. YSI 2700 Select Biochemistry Analyzer. User's Manual. YSI Inc., Yellow Springs, OH. 